J-SISKO TECH

Jurnal Teknologi Sistem Informasi dan Sistem Komputer TGD

P:ISSN : 2621-8976 E-ISSN : 2615-5133

Vol.3, No.1, Januari 2020, pp.19-31

\title{
Sistem Pendukung Keputusan Kelayakan Pembuatan Jaringan Baru Instalasi Pipa Air Untuk Distribusi Masyarakat Pada PDAM Tirtanadi Menggunakan Metode Moora
}

\author{
*Hendra Jaya, Hendryan Winata, Ita Mariami \\ Program Studi Sistem Informasi, STMIK Triguna Dharma \\ Jl. A.H Nasution No.73 Medan, Indonesia, 20142 \\ E-mail : hendra_jaya@trigunadharma.ac.id
}

\section{E-mail:}

\begin{abstract}
Abstrak
Dalam instalasi pipa distribusi PDAM Tirtanadi terkadanag masih banyak mengalami kendala, salah satunya tidak sesuainya jumlah pengguna air dengan air yang didistribusikan, sehingga pihak PDAM mengalami banyak kerugian untuk biaya operasional ataupun kerugian kelebihan air. Dengan alasan itulah maka diangkat penelitian dengan judul "Sistem Pendukung Keputusan Kelayakan Pembuatan Jaringan Baru Instalasi Pipa Air Untuk Distribusi Masyarakat Pada PDAM Tirtanadi Menggunakan Metode MOORA". Penelitian tersebut bertujuan untuk menciptakan suatu sistem berbasis komputerisasi, kemudian dengan diterapkannya sistem tersebut maka hasil yang didapatkan akan benar-benar akurat dan cepat kemudian dapat membantu PDAM Tirtandi dalam menentukan kelayakan pembuatan jaringan baru instalasi pipa air untuk distribusi masyarakat. Dapat dikatakan bahwa dengan pengujian sistem berdasarkan kriteria-kriteria yang diinputkan atas alternatif akan memberikan jawaban pasti wilayah mana yang benar-benar layak untuk di lakukan instalasi jaringan baru pipa air berdasarkan nilai akhir yang didapat. Hal ini karena penerapan metode yang di masukkan ke dalam coding program sehingga sistem ini dapat membantu PDAM Tirtanadi dalam menentukan kelayakan pembuatan jaringan baru instalasi pipa air untuk distribusi masyarakat.
\end{abstract}

Kata kunci : Instalasi Pipa Air, PDAM Tirtanadi, Sistem Pendukung Keputusan, Metode MOORA

\begin{abstract}
In the distribution pipe installation of PDAM Tirtanadi, there are still many obstacles, one of which is the incompatibility of the number of water users with the water that is distributed, so that the PDAM experiences a lot of losses for operational costs or excess water losses. For this reason, a research entitled "Decision Support System for Making a New Network for Water Distribution for Community Distribution at PDAM Tirtanadi was adopted using the MOORA Method". The research aims to create a computerized system, then by implementing the system the results obtained will be truly accurate and fast and can then assist PDAM Tirtandi in determining the feasibility of making a new network of water pipe installations for community distribution. It can be said that by testing the system based on the criteria inputted on the alternative, it will give a definite answer which region is really feasible to do a new pipeline network installation based on the final value obtained. This is because the application of the
\end{abstract}


method included in the coding program so that this system can assist PDAM Tirtanadi in determining the feasibility of making a new network of water pipe installations for community distribution

Keywords: Water Pipe Installation, PDAM Tirtanadi, Decision Support System, MOORA Method

\section{PENDAHULUAN}

Perusahaan Daerah Air Minum (PDAM) Tirtanadi merupakan salah satu perusahaan yang dimiliki oleh Badan Usaha Milik Daerah (BUMD) Kota Medan. PDAM Tirtanadi dibangun oleh Pemerintahan Kolonial Belanda pada tanggal 8 September 1905 yang diberi nama NV Waterleiding Maatschappij Ajer Beresih. Setelah kemerdekaan Indonesia, perusahaan ini diserahkan kepada Pemerintah Provinsi Sumatera Utara melalui Pemerintah Indonesia. Berdasarkan Perda Sumatera Utara No 11 tahun 1979, status perusahaan diubah menjadi PDAM Tirtanadi Provinsi Sumatera Utara. PDAM Tirtanadi memiliki 13 cabang untuk wilayah Kota Medan.

Kebutuhan terhadap air untuk keperluan sehari-hari dilingkungan rumah tangga, ternyata berbeda untuk tiap tempat, tiap tingkatan kehidupan atau untuk tiap bangsa dan negara. Semakin tinggi taraf kehidupan, semakin meningkat pula kebutuhan manusia terhadap air. Karena begitu pentingnya peranan air ini dalam kehidupan masyarakat, maka pemerintah perlu atau harus memberi perhatian khusus. Dikarenakan terus meningkatnya penggunaan air di Kota Medan dengan peningkatan rata-rata 3400 sambungan per tahun, membuat PDAM Tirtanadi harus banyak melakukan instalasi pipa-pipa distirbusi (Harahap Dkk, 2013:326).

Dalam pendistribusian kepada masyarakat, PDAM Tirtanadi menggunakan pipa-pipa yang terdiri dari pipa induk, pipa distirbusi dan pipa saluran. Pipa induk yaitu sebagai penyalur air dari pengolahan air ke titik-titik tertentu sekitaran daerah pemukiman masyarakat. Pipa distribusi merupakan pipa yang menyalurkan air dari pipa induk ke lingkungan sekitar masyarakat, pipa disrtibusi ukurannya lebih kecil dari pipa induk. Sedangkan pipa saluran adalah pipa yang menyalurkan air dari pipa distribusi ke rumah-rumah warga, pipa saluran ukurannya lebih kecil dari pipa distribusi. Namun dalam instalasi pipa distribusi terkadanag masih banyak mengalami kendala, salah satunya tidak sesuainya jumlah pengguna air dengan air yang didistribusikan, sehingga pihak PDAM mengalami banyak kerugian untuk biaya operasional ataupun kerugian kelebihan air (PDAM Tirtanadi). Untuk mengatasi masalah tersebut, salah satu teknik yang dapat digunakan yaitu dengan Sistem Pendukung Keputusan.

Sistem Pendukung Keputusan merupakan suatu sistem berbasis komputer yang membantu pengambilan keputusan dengan memanfaatkan data dan model-model untuk menyelesaikan masalah-masalah yang tidak terstruktur. Dalam sistem pendukung keputusan terdapat beberapa jenis metode sesuai dengan pemanfaatannya, salah satunya metode MOORA (Multi Objective Optimization on the Basic of Ratio Analysis). Metode MOORA adalah metode yang diperkenalkan oleh Brauers dan Zavadkas (2006). Metode yang relatif baru ini pertama kali digunakan oleh Brauers (2003) dalam suatu pengambilan dengan multi kriteria. Metode ini memiliki tingkat selektifitas yang baik karena dapat menentukan tujuan dari kriteria yang bertentangan. Dimana kriteria dapat bernilai menguntungkan (benefit) atau yang tidak menguntungkan (cost) (Manurung,2018:2). Dalam masalah yang dibahas pada penelitian ini akan di rancang sebuah perangkat lunak berbasis Dekstop Programming yang diharapkan menjadi solusi pemecahan masalah.

Dekstop Programming adalah salah satu pemrograman yang fokus untuk membuat suatu sistem perangkat lunak yang mengolah data numerik atau aritmatik. Perangkat lunak yang di rancang akan memakai metode MOORA. Pada konsep perancangan yang dilakukan yaitu membangun suatu aplikasi sistem pendukung keputusan dengan

J-SISKO TECH Vol.3, No.1, 2020: 19-31 
memasukkan kriteria-kriteria yang ada dan pada fase akhir akan dilakukan pengujian sistemnya sehingga dapat menyelesaikan masalah sesuai dengan yang diharapkan.

\section{METODE PENELITIAN}

\subsection{Sistem Distribusi Air Bersih}

Menurut Damanhuri, E., (1989) sistem distribusi adalah sistem yang langsung berhubungan dengan konsumen, yang mempunyai fungsi pokok mendistribusikan air yang telah memenuhi syarat ke seluruh daerah pelayanan.Sistem ini meliputi unsur sistem perpipaan dan perlengkapannya, hidran kebakaran, tekanan tersedia, sistem pemompaan, dan reservoir distribusi. Sistem distribusi air minum terdiri atas perpipaan, katup-katup, dan pompa yang membawa air yang telah diolah dari instalasi pengolahan menujupemukiman, perkantoran dan industri yang mengkonsumsi air. Juga termasuk dalam sistem ini adalah fasilitas penampung air yang telah diolah (reservoir distribusi), yang digunakan saat kebutuhan air lebih besar dari suplai instalasi, meter air untuk menentukan banyak air yang digunakan, dan keran kebakaran. Dua hal penting yang harus diperhatikan pada sistem distribusi adalah tersedianya jumlah air yang cukup dan tekanan yang memenuhi (kontinuitas pelayanan), serta menjaga keamanan kualitas air yang berasal dari instalasi pengolahan.

\subsection{Sistem Pendukung Keputusan}

Sistem Pendukung Keputusan (Decision Support Systems) adalah sebuah sistem yang dimaksudkan untuk mendukung para pengambil keputusan manajerial dalam situasi keputusan semiterstruktur (Muqtadir dan Purdianto, 2013:49). Sistem pendukung keputusan dapat diartikan sebagai suatu sistem yang dirancang yang digunakan untuk mendukung manajemen di dalam pengambilan keputusan (Nofriansyah dan Defit, 2017:1).

\subsection{Metode MOORA}

Multi-Objective Optimization on the basis of ratio Analysis (MOORA) adalah multiobjektif sistem mengoptimalkan dua atau lebih attribut yang saling bertentangan secara bersamaan. Metode ini diterapkan untuk memecahkan masalah dengan perhitungan matematika yang kompleks. Moora diperkenalkan oleh Brauers dan Zavadskas pada tahun 2006. Pada awalnya metode ini diperkenalkan oleh Brauers pada tahun 2004 sebagai "Multi-Objective Optimization" yang dapat digunakan untuk memecahkan berbagai masalah pengambilan keputusan yang rumit pada lingkungan pabrik. "Metode MOORA diterapkan untuk memecahkan banyak permasalahan ekonomi, manajerial dan kontruksi pada sebuah perusahaan maupun proyek." (Nofriansyah dan Defit, 2017:85). "Metode moora memiliki tingkat fleksibelitas dan kemudahan untuk dipahami dalam memisahkan bagian subjektif dari suatu proses evaluasi kedalam kriteria bobot keputusan dengan beberapa atribut pengambilan keputusan" (Mandal dan Sarlar, 2012). Metode ini memiliki tingkat selektifitas yang baik karena dapat menentukan tujuan dari kriteria yang bertentangan. Dimana kriteria dapat bernilai menguntungkan (benefit) atau yang tidak menguntungkan (cost). Berikut ini adalah algoritma penyelesaian metode moora yaitu sebagai berikut :

1. Langkah Pertama : Menginput nilai kriteria. Menginputkan nilai kriteria pada suatu alternatif dimana nilai tersebut nantinya akan diproses dan hasilnya akan menjadi sebuah keputusan.

2. Langkah Kedua : Merubah nilai kriteria menjadi matriks keputusan. Metriks keputusan berfungsi sebagai pengukuran kinerja dari alternatif $\mathrm{I}$ th pada atribut $\mathrm{J}$ th, $\mathrm{M}$ adalah alternatif dan $\mathrm{n}$ adalah jumlah atribut dan kemudian sistem rasio dikembangkan dimana setiap kinerja dari sebuah alternatif pada sebuah atribut dibandingkan dengan penyebut yang merupakan wakil untuk semua alternatif dari atribut tersebut. Berikut adalah perubahan nilai kriteria menjadi sebuah matriks keputusan: 
3. $\mathrm{X}=\left[\begin{array}{lll}x_{11} & x_{12} & x_{1 n} \\ x_{21} & x_{22} & x_{2 n} \\ x_{m 1} & x_{m 2} & x_{m n}\end{array}\right]$

4. Langkah Ketiga : Normalisasi pada metode Moora. Normalisasi bertujuan untuk menyatukan setiap element matriks sehingga element pada matriks memiliki nilai yang seragam. Normalisasi pada Moora dapat dihitung menggunakan persamaan sebagai berikut:

$$
X_{i f}^{*}=X_{i f} / \sqrt{\left[\sum_{i=1}^{m} X_{i j}^{2}\right]}
$$

5. Langkah Keempat : Mengurangi nilai maximax dan minmax. Untuk mendapatkan bahwa sebuah atribut lebih penting itu bias dikalikan dengan bobot yang sesuai (koefisien signifikasi). (Brauers etal. 2009 dalam Ozcelik, 2014) saat atribut bobot dipertimbangkan perhitungan menggunakan persamaan sebagai berikut:

$$
Y_{i}=\sum_{j=1}^{g} W_{f} X_{i j}^{*}-\sum_{j=g+1}^{n} W_{f} W_{i f}^{*}
$$

Langkah Kelima : Menentukan rangking dari hasil perhitungan MOORA. Langkah terakhir yang dilakukan yaitu membuat perangkingan untuk hasil perhitungan MOORA dengan cara mengurutkan dari hasil yang paling besar ke hasil yang paling kecil.

\subsection{Analisa dan Hasil}

Algoritma sistem merupakan suatu tahapan yang dilakukan sebelum proses kelayakan pembuatan jaringan baru instalasi pipa air untuk distribusi masyarakat pada PDAM Tirtanadi. Adapun algoritma sistem penyelesaian dengan metode MOORA adalah sebagai berikut:

1. Menginput nilai kriteria.

2. Merubah nilai kriteria menjadi matriks keputusan.

3. Normalisasi pada metode Moora.

4. Mengurangi nilai maximax dan minimax.

5. Menentukan rangking dari hasil perhitungan MOORA.

\subsubsection{Menginput Nilai Kriteria}

Berikut ini adalah data nilai kriteria kelayakan pembuatan jaringan baru instalasi pipa air untuk distribusi masyarakat pada PDAM Tirtanadi.

Tabel 3.1 Nilai Bobot Kriteria

\begin{tabular}{|c|c|l|c|}
\hline No & Kode & \multicolumn{1}{|c|}{ Nama Kriteria } & $\begin{array}{c}\text { Nilai } \\
\text { Bobot } \\
\left(\boldsymbol{W}_{f}\right)\end{array}$ \\
\hline 1 & C1 & $\begin{array}{l}\text { Adanya Pipa Induk } \\
\text { Disekitar Titik Yang Akan } \\
\text { di Instalasi }\end{array}$ & 0,30 \\
\hline 2 & C2 & $\begin{array}{l}\text { Jarak Titik Instalasi Dari } \\
\text { Pipa Induk }\end{array}$ & 0,20 \\
\hline 3 & C3 & Jumlah Pengguna & 0,30 \\
\hline 4 & C4 & Keadaan Bentuk Tanah & 0,20 \\
\hline
\end{tabular}

Selanjutnya membuat tabel sub kriteria adanya pipa induk disekitar titik yang akan di instalasi sebagai penilaian kelayakan pembuatan jaringan baru instalasi pipa air untuk distribusi masyarakat, yaitu sebagai berikut: 
Tabel 3.2 Sub Kriteria Adanya Pipa Induk Disekitar Titik Yang Akan di Instalasi

\begin{tabular}{|c|c|c|}
\hline No & Adanya Pipa Induk & Bobot \\
\hline 1 & Tidak & 1 \\
\hline 2 & Ya & 2 \\
\hline
\end{tabular}

Kemudian membuat tabel sub kriteria jarak titik instalasi dari pipa induk, yaitu sebagai berikut:

Tabel 3.3 Sub Kriteria Jarak Titik Instalasi Dari Pipa Induk

\begin{tabular}{|c|c|c|}
\hline No & Jarak Pipa & Bobot \\
\hline 1 & $>800 \mathrm{M}$ & 1 \\
\hline 2 & $>600-800 \mathrm{M}$ & 2 \\
\hline 3 & $>400-600 \mathrm{M}$ & 3 \\
\hline 4 & $>200-400 \mathrm{M}$ & 4 \\
\hline 5 & $<=200 \mathrm{M}$ & 5 \\
\hline
\end{tabular}

Kemudian membuat tabel sub kriteria jumlah pengguna, yaitu sebagai berikut:

Tabel 3.4 Sub Kriteria Jumlah Pengguna

\begin{tabular}{|c|c|c|}
\hline No & Jumlah Pengguna & Bobot \\
\hline 1 & $<=20$ Pengguna & 1 \\
\hline 2 & $>20-40$ Pengguna & 2 \\
\hline 3 & $>40-60$ Pengguna & 3 \\
\hline 4 & $>60-80$ Pengguna & 4 \\
\hline 5 & $>80$ Pengguna & 5 \\
\hline
\end{tabular}

Kemudian membuat tabel sub kriteria keadaan bentuk tanah, yaitu sebagai berikut:

Tabel 3.5 Sub Kriteria Keadaan Bentuk Tanah

\begin{tabular}{|c|c|c|}
\hline No & Bentuk Tanah & Bobot \\
\hline 1 & Bergelombang & 1 \\
\hline 2 & Miring & 2 \\
\hline 3 & Rata & 3 \\
\hline
\end{tabular}

Selanjutnya membuat data yang akan dijadikan sebagai alternatif dalam menentukan kelayakan pembuatan jaringan baru instalasi pipa air untuk distribusi masyarakat pada PDAM Tirtanadi. Berikut ini adalah data barang pada PT. Trans Retail Indonesia.

Tabel 3.6 Tabel Data Alternatif

\begin{tabular}{|c|c|c|}
\hline $\begin{array}{c}\text { N } \\
\text { o }\end{array}$ & $\begin{array}{c}\text { Alternat } \\
\text { if }\end{array}$ & Alamat \\
\hline 1. & A1 & Jl. Kelambir 5 Gg. Hasanah I \\
\hline 2. & A2 & Jl. Kelambir 5 Gg. Haikal II \\
\hline 3. & A3 & Jl. Kelambir 5 Gg. Atik Pilis \\
\hline 4. & A4 & Jl. Kelambir 5 Gg. Husman \\
\hline 5. & A5 & Jl. Kelambir 5 Gg. Warisan I \\
\hline 6. & A6 & Jl. Kelambir 5 Gg. Warisan II \\
\hline
\end{tabular}

\subsubsection{Merubah Nilai Kriteria Menjadi Matriks Keputusan}


Sebelum merubah nilai kriteria menjadi matriks keputusan, yang harus dilakukan yaitu memberikan nilai alternatif untuk setiap kriteria. Berikut ini adalah data nilai alternatif yang ada pada tabel 3.6, yaitu sebagai berikut:

Tabel 3.7 Tabel Nilai Alternatif

\begin{tabular}{|c|l|c|c|c|c|}
\hline No & \multicolumn{1}{|c|}{ Alamat } & $\begin{array}{c}\text { Adanya } \\
\text { Pipa } \\
\text { Induk }\end{array}$ & $\begin{array}{c}\text { Jarak } \\
\text { Pipa }\end{array}$ & $\begin{array}{c}\text { Jumlah } \\
\text { Pengguna }\end{array}$ & $\begin{array}{c}\text { Bent } \\
\text { uk } \\
\text { Tana } \\
\mathbf{h}\end{array}$ \\
\hline 1 & Jl. Kelambir 5 Gg. Hasanah I & Tidak & $\begin{array}{c}400 \\
\text { M }\end{array}$ & $\begin{array}{c}50 \\
\text { Pengguna }\end{array}$ & Miring \\
\hline 2 & Jl. Kelambir 5 Gg. Haikal II & Ya & $\begin{array}{c}600 \\
\text { M }\end{array}$ & $\begin{array}{c}80 \\
\text { Pengguna }\end{array}$ & Rata \\
\hline 3 & Jl. Kelambir 5 Gg. Atik Pilis & Ya & $\begin{array}{c}800 \\
\text { M }\end{array}$ & $\begin{array}{c}90 \\
\text { Pengguna }\end{array}$ & Miring \\
\hline 4 & Jl. Kelambir 5 Gg. HUsman & Ya & $\begin{array}{c}500 \\
\text { M }\end{array}$ & $\begin{array}{c}50 \\
\text { Pengguna }\end{array}$ & Rata \\
\hline 5 & Jl. Kelambir 5 Gg. Warisan I & Tidak & $\begin{array}{c}500 \\
\text { M }\end{array}$ & $\begin{array}{c}70 \\
\text { Pengguna }\end{array}$ & Miring \\
\hline 6 & Jl. Kelambir 5 Gg. Warisan II & Ya & $\begin{array}{c}600 \\
\text { M }\end{array}$ & $\begin{array}{c}80 \\
\text { Pengguna }\end{array}$ & Miring \\
\hline
\end{tabular}

Berikut ini adalah nilai alternatif untuk setiap kriteria. Berikut ini adalah nilai alternatif pada untuk setiap kriteria.

Tabel 3.8 Tabel Penilaian Alternatif Pada Setiap Kriteria

\begin{tabular}{|c|c|c|c|c|c|c|}
\hline $\mathbf{N}$ & \multicolumn{3}{|c|}{ Alternatif } & \multicolumn{4}{c|}{ Kriteria } \\
$\mathbf{0}$ & Kode & Alamat & C1 & C2 & C3 & C4 \\
\hline 1 & A1 & Jl. Kelambir 5 Gg. Hasanah I & 1 & 4 & 3 & 2 \\
\hline 2 & A2 & Jl. Kelambir 5 Gg. Haikal II & 2 & 3 & 4 & 3 \\
\hline 3 & A3 & Jl. Kelambir 5 Gg. Atik Pilis & 2 & 2 & 5 & 2 \\
\hline 4 & A4 & Jl. Kelambir 5 Gg. Husman & 2 & 3 & 3 & 3 \\
\hline 5 & A5 & Jl. Kelambir 5 Gg. Warisan I & 1 & 3 & 4 & 2 \\
\hline 6 & A6 & Jl. Kelambir 5 Gg. Warisan II & 2 & 3 & 4 & 2 \\
\hline \multicolumn{7}{|c|}{ Optimum } \\
\hline
\end{tabular}

Setelah mengetahui nilai alternatif pada setiap kriteria, selanjutnya merubah nilai kritria menjadi matriks keputusan. Berikut ini adalah nilai matriks keputusannya.

$$
X=\left[\begin{array}{llll}
1 & 4 & 3 & 2 \\
2 & 3 & 4 & 3 \\
2 & 2 & 5 & 2 \\
2 & 3 & 3 & 3 \\
1 & 3 & 4 & 2 \\
2 & 3 & 4 & 2
\end{array}\right]
$$

\subsubsection{Normalisasi Pada Metode Moora}

Setelah dilakukan perubahan, selanjutnya melakukan normalisasi. Berikut ini adalah normalisasi data tersebut.

$X_{i j}^{i}=X_{i j} / \sqrt{\left[\sum_{i=1}^{m} X_{i j}^{2}\right]}$

1. Kriteria 1 (C1)

$$
\begin{aligned}
& \sqrt{1^{2}+2^{2}+2^{2}+2^{2}+1^{2}+2^{2}}=4,2426 \\
& A_{11}=1 / 4,2426=0,2357
\end{aligned}
$$

J-SISKO TECH Vol.3, No.1, 2020: 19-31 


$$
\begin{aligned}
& A_{21}=2 / 4,2426=0,4714 \\
& A_{91}=2 / 4,2426=0,4714 \\
& A_{41}=2 / 4,2426=0,4714 \\
& A_{51}=1 / 4,2426=0,2357 \\
& A_{61}=2 / 4,2426=0,4714
\end{aligned}
$$

2. Kriteria $2(\mathrm{C} 2)$

$$
\begin{aligned}
& \sqrt{4^{2}+3^{2}+2^{2}+3^{2}+3^{2}+3^{2}}=7,4833 \\
& A_{12}=4 / 7,4833=0,5345 \\
& A_{22}=3 / 7,4833=0,4009 \\
& A_{22}=2 / 7,4833=0,2673 \\
& A_{42}=3 / 7,4833=0,4009 \\
& A_{52}=3 / 7,4833=0,4009 \\
& A_{62}=3 / 7,4833=0,4009
\end{aligned}
$$

3. Kriteria 3 (C3)

$$
\begin{aligned}
& \sqrt{3^{2}+4^{2}+5^{2}+3^{2}+4^{2}+4^{2}}=9,5394 \\
& A_{13}=3 / 9,5394=0,3145 \\
& A_{23}=4 / 9,5394=0,4193 \\
& A_{23}=5 / 9,5394=0,5241 \\
& A_{43}=3 / 9,5394=0,3145 \\
& A_{53}=4 / 9,5394=0,4193 \\
& A_{63}=4 / 9,5394=0,4193
\end{aligned}
$$

4. Kriteria 4 (C4)

$$
\begin{aligned}
& \sqrt{2^{2}+3^{2}+2^{2}+3^{2}+2^{2}+2^{2}}=5,831 \\
& A_{14}=2 / 5,831=0,343 \\
& A_{24}=3 / 5,831=0,5145 \\
& A_{24}=2 / 5,831=0,343 \\
& A_{44}=3 / 5,831=0,5145 \\
& A_{54}=2 / 5,831=0,343 \\
& A_{64}=2 / 5,831=0,343
\end{aligned}
$$

Berdasarkan perhitungan di atas, berikut ini adalah matriks ternormalisasi yaitu sebagai berikut:

$$
X_{i j}=\left[\begin{array}{cccc}
0,2357 & 0,5345 & 0,3145 & 0,343 \\
0,4714 & 0,4009 & 0,4193 & 0,5145 \\
0,4714 & 0,2673 & 0,5241 & 0,343 \\
0,4714 & 0,4009 & 0,3145 & 0,5145 \\
0,2357 & 0,4009 & 0,4193 & 0,343 \\
0,4714 & 0,4009 & 0,4193 & 0,343
\end{array}\right]
$$

Selanjutnya yaitu mengoptimalisasi nilai atribut:

$$
Y=X_{i j} * W_{j}
$$


$X=\left[\begin{array}{cccc}0,2357 & 0,5345 & 0,3145 & 0,343 \\ 0,4714 & 0,4009 & 0,4193 & 0,5145 \\ 0,4714 & 0,2673 & 0,5241 & 0,343 \\ 0,4714 & 0,4009 & 0,3145 & 0,5145 \\ 0,2357 & 0,4009 & 0,4193 & 0,343 \\ 0,4714 & 0,4009 & 0,4193 & 0,343\end{array}\right] \times\left[\begin{array}{llll}0.30 & 0.20 & 0.30 & 0.20\end{array}\right]$

Maka nilai $X_{\mathrm{i} j} * W_{j}$ yaitu sebagai berikut:

$\left[\begin{array}{llll}0,0707 & 0,1069 & 0,0944 & 0,0686\end{array}\right]$

$\begin{array}{llll}0,1414 & 0,0802 & 0,1258 & 0,1029\end{array}$

$X=$

$\begin{array}{lllll}0,1414 & 0,0535 & 0,1572 & 0,0686\end{array}$

$\begin{array}{lllll}0,1414 & 0,0802 & 0,0944 & 0,1029\end{array}$

$\begin{array}{lllll}0,0707 & 0,0802 & 0,1258 & 0,0686\end{array}$

$\left[\begin{array}{llll}0,1414 & 0,0802 & 0,1258 & 0,0686\end{array}\right]$

\subsubsection{Mengurangi Nilai Maximax Dan Minimax}

Kemudian setelah melakukan perkalian antara $X_{i j}$ dan $W_{j}$, maka berikutnya adalah menghitung nilai $Y_{i}$ yang terlihat pada tabel di bawah ini:

Tabel 3.9 Tabel Mencari Nilai $Y_{i}$

\begin{tabular}{|c|c|c|c|}
\hline Alternatif & $\begin{array}{c}\text { Maximum } \\
(\mathbf{C} 1+\mathbf{C 3})\end{array}$ & $\begin{array}{c}\text { Minimum } \\
(\mathbf{C} 2+\mathbf{C 4})\end{array}$ & $\begin{array}{c}\boldsymbol{Y}_{\tilde{i}} \\
(\mathbf{M a x}-\mathbf{M i n})\end{array}$ \\
\hline A1 & 0,1651 & 0,1755 & $-0,0105$ \\
\hline A2 & 0,2672 & 0,1831 & 0,0841 \\
\hline A3 & 0,2987 & 0,1221 & 0,1766 \\
\hline A4 & 0,2358 & 0,1831 & 0,0527 \\
\hline A5 & 0,1965 & 0,1488 & 0,0477 \\
\hline A6 & 0,2672 & 0,1488 & 0,1184 \\
\hline
\end{tabular}

\subsubsection{Menentukan Rangking Dari Hasil Perhitungan MOORA}

Selanjutnya yang terakhir yaitu melakukan perangkingan. Berdasarkan tabel di atas, maka berikut ini adalah hasil perangkingannya:

Tabel 3.10 Tabel Perangkingan

\begin{tabular}{|c|c|c|c|}
\hline Alternatif & $\begin{array}{c}\boldsymbol{Y}_{\tilde{i}} \\
\text { (Max - Min) }\end{array}$ & Rangking & Keterangan \\
\hline A3 & 0,1766 & Rangking 1 & Layak \\
\hline A6 & 0,1184 & Rangking 2 & Layak \\
\hline A2 & 0,0841 & Rangking 3 & Layak \\
\hline A4 & 0,0527 & Rangking 4 & Layak \\
\hline A5 & 0,0477 & Rangking 5 & Tidak Layak \\
\hline A1 & $-0,0105$ & Rangking 6 & Tidak Layak \\
\hline
\end{tabular}

Dari hasil di atas, dapat diketahui bahwa yang memiliki nilai akhir dibawah 0,05 maka dinyakatan tidak layak untuk dilakukan pembuatan jaringan baru instalasi pipa air untuk distribusi masyarakat.Sistem ini dibangun untuk kelayakan pembuatan jaringan baru instalasi pipa air untuk distribusi masyarakat pada PDAM Tirtanadi. Dalam hal ini proses tersebut menggunakan metode MOORA. Melalui proses MOORA dilakukan tahap penentuan data kemudian kriteria. Setelah menentukan kriteria dari data tersebut maka selanjutnya melakukan perhitungan dalam menentukan kelayakan pembuatan jaringan baru instalasi pipa air untuk distribusi masyarakat pada PDAM Tirtanadi. 
Permasalahan yang muncul pada saat diadakannya penentuan perhitungan dalam kelayakan pembuatan jaringan baru instalasi pipa air untuk distribusi masyarakat pada PDAM Tirtanadi yang dilakukan ternyata masih belum bisa mendekati sasaran yang tepat. Sering sekali mengalami beberapa kesalahan dalam perhitungan untuk kelayakan pembuatan jaringan baru instalasi pipa air untuk distribusi masyarakat pada PDAM Tirtanadi.

Dari permasalahan tersebut maka dilakukan pengolahan data dalam hal pemprosesan untuk menentukan kelayakan pembuatan jaringan baru instalasi pipa air untuk distribusi masyarakat pada PDAM Tirtanadi menggunakan metode MOORA dari data awal sampai terbentuknya laporan.

1. Tampilan Form Login

Berikut ini merupakan tampilan dari form login yang berfungsi untuk melakukan proses validasi username dan password pengguna.

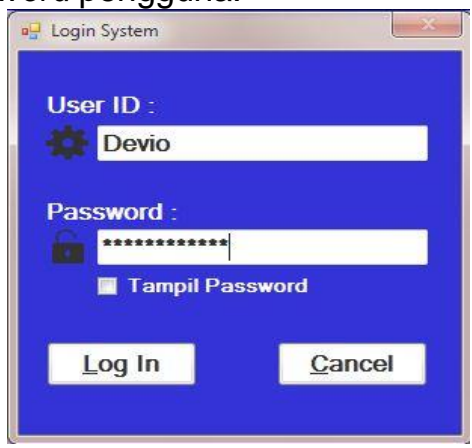

Gambar 1. Form Login

2. Tampilan Menu Utama

Berikut ini merupakan tampilan menu utama dari sistem pendukung keputusan kelayakan pembuatan jaringan baru instalasi pipa air untuk distribusi masyarakat:

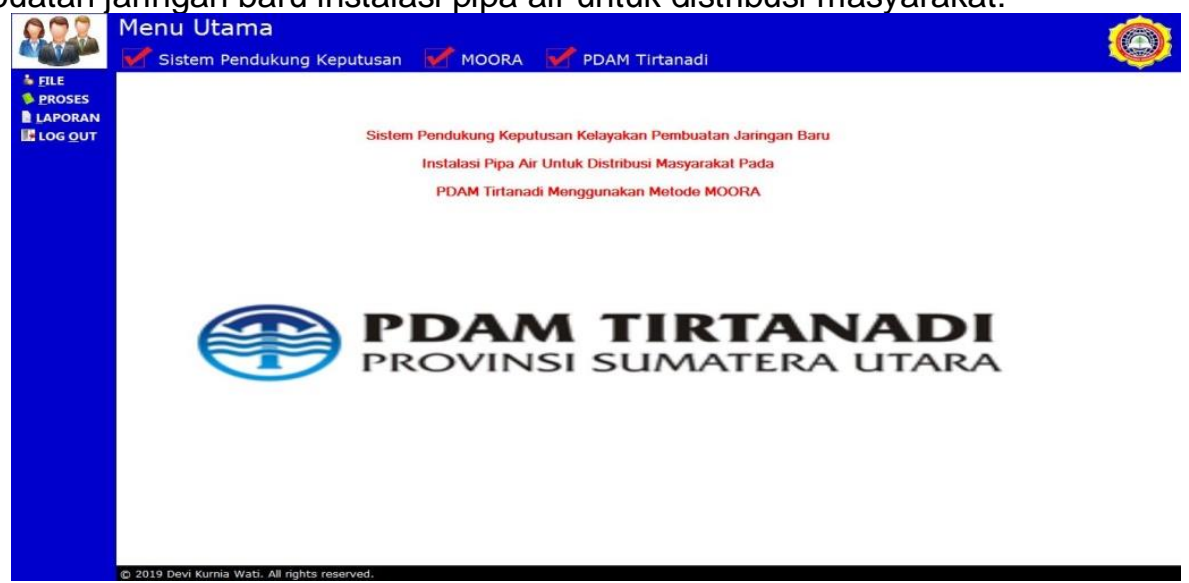

Gambar 2. Form Menu Utama

3. Form Masukan Data Survei

Berikut ini merupakan tampilan dari form masukan data survei yang berfungsi untuk menginput data-data hasil survei lokasi untuk instalasi jaringan pipa baru: 


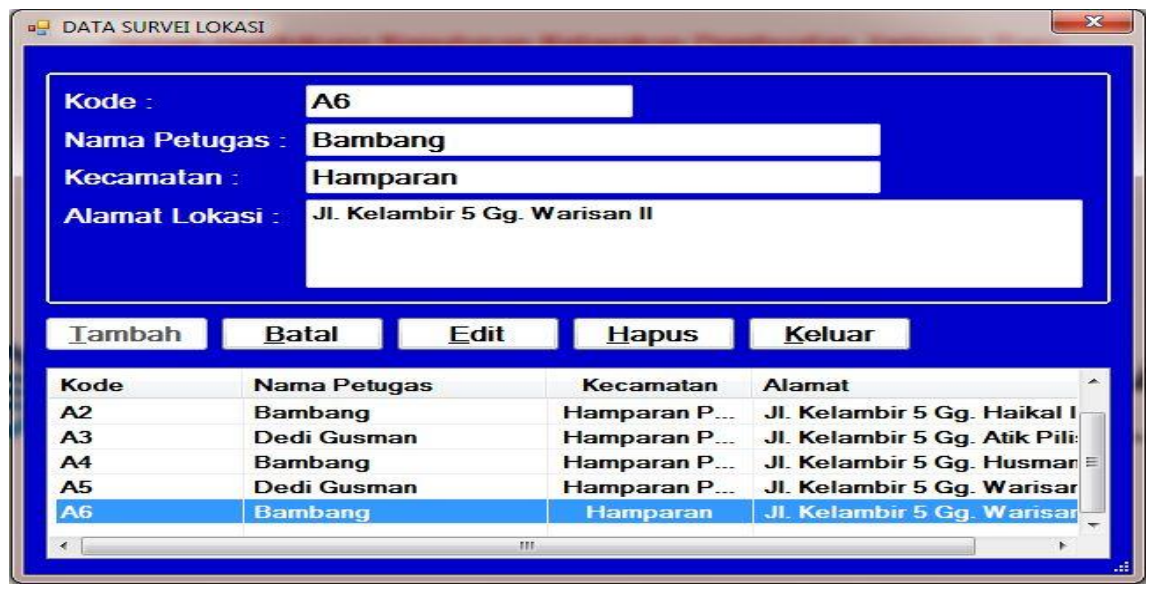

Gambar 3. Form Masukan Data Survei

4. Form Data Kriteria

Berikut ini merupakan tampilan dari form data kriteria yang berfungsi untuk menginput datadata kriteria:

\begin{tabular}{|c|c|c|}
\hline \multicolumn{3}{|l|}{ DATA KRITERIA } \\
\hline Kode : & C4 & \\
\hline Kriteria & Keadaan Bentuk Tanah & \\
\hline Nilai Bobot & 0.2 & \\
\hline Iambah & Hapus & Keluar \\
\hline Kode & Kriteria & Bobot \\
\hline C1 & Adanya Pipa Induk Disekitar Titik Y.. & 0.3 \\
\hline $\mathrm{C} 2$ & Jarak Titik Instalasi Dari Pipa Induk & 0.2 \\
\hline C3 & Jumlah Pengguna & 0.3 \\
\hline $\mathrm{CA}$ & Keadaan Bentuk Tanah & 0.2 \\
\hline
\end{tabular}

Gambar 4. Tampilan Form Data Kriteria

5. Form Proses Perhitungan

Berikut ini merupakan tampilan dari form proses perhitungan yang berfungsi untuk memproses perhitungan dengan metode MOORA: 


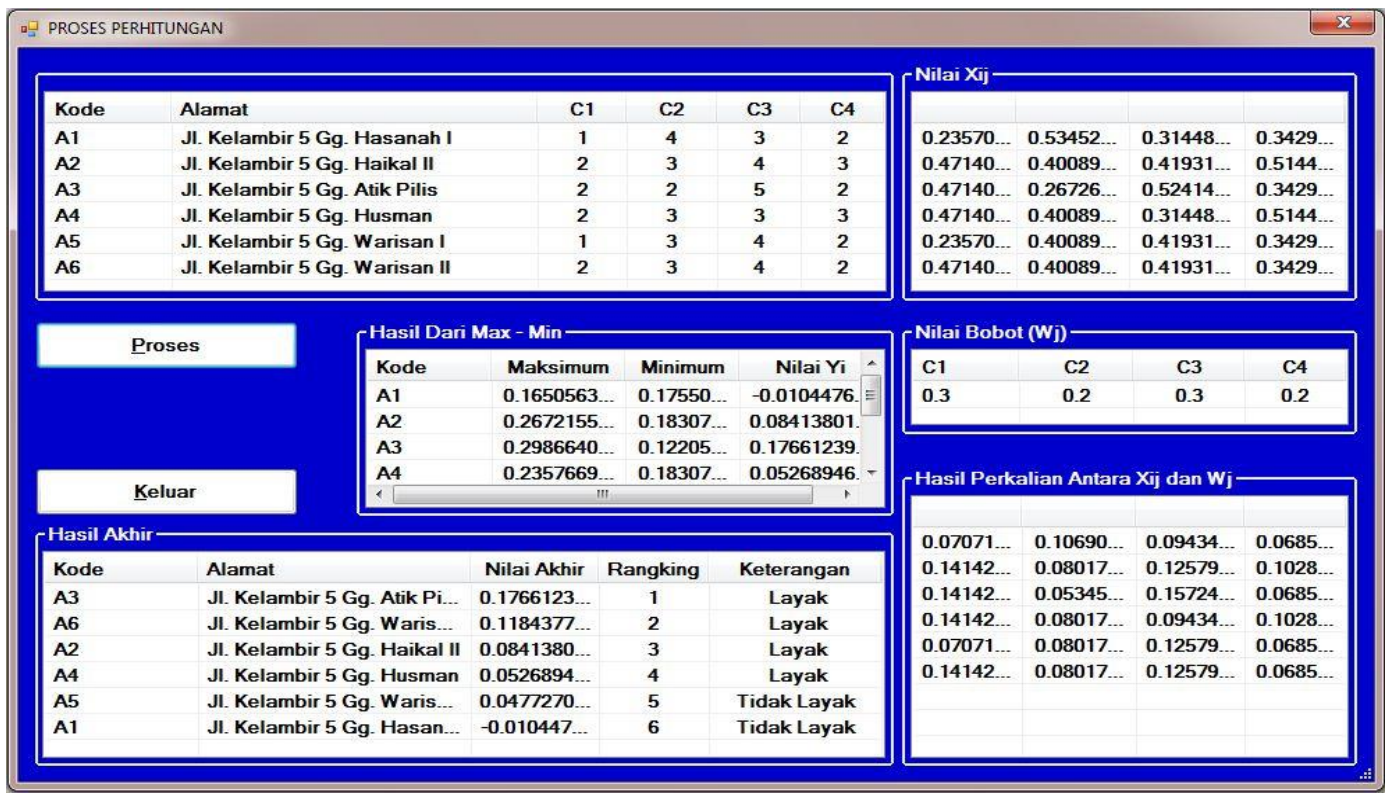

Gambar 5. Tampilan Form Proses Perhitungan

6. Tampilan Form Laporan Hasil

Laporan ini berfungsi untuk menampilkan data hasil perhitungan untuk kelayakan pembuatan jaringan baru instalasi pipa air untuk distribusi masyarakat.

\section{LAPORAN HASIL KEPUTUSAN}

J1. Binjai Km. 13,2 No. 8

Telp. (061) 8460984

\section{LAPORAN HASIL KEPUTUSAN}

\begin{tabular}{|l|l|c|c|c|}
\hline Kode & \multicolumn{1}{|c|}{ Alamat } & Nilai Akhir & Rangking & Keterangan \\
\hline A3 & ת. Kelambir 5 Gg. Atik Pilis & 0.1766 & 1 & Layak \\
A6 & ת. Kelambir 5 Gg. Warisan II & 0.1184 & 2 & Layak \\
A2 & ת. Kelambir 5 Gg. Haikal II & 0.0841 & 3 & Layak \\
A4 & ת. Kelambir 5 Gg. Husman & 0.0527 & 4 & Layak \\
A5 & Л. Kelambir 5 Gg. Warisan I & 0.0477 & 5 & Tidak Layak \\
A1 & ת. Kelambir 5 Gg. Hasanah I & -0.0104 & 6 & Tidak Layak \\
\hline
\end{tabular}

Medan, 25-March-2019

Diketahui Oleh,

Kabag. Survei

Gambar 6. Tampilan Laporan Hasil 
Pada laporan hasil perhitungan diatas diketahui hasil kelayakan pembuatan jaringan baru instalasi pipa air untuk distribusi masyarakat.

\begin{tabular}{|c|c|c|c|c|}
\hline Kode & Alamat & Nilai Akhir & Rangking & Keterangan \\
\hline A3 & Jl. Kelambir 5 Gg. Atik Pi... & 0.1766123 & 1 & Layak \\
\hline A6 & Jl. Kelambir 5 Gg. Waris... & $0.1184377 \ldots$ & 2 & Layak \\
\hline A2 & Jl. Kelambir 5 Gg. Haikal II & 0.0841380 & 3 & Layak \\
\hline A4 & Jl. Kelambir 5 Gg. Husman & $0.0526894 \ldots$ & 4 & Layak \\
\hline A5 & Jl. Kelambir 5 Gg. Waris... & $0.0477270 \ldots$ & 5 & Tidak Layak \\
\hline A1 & JI. Kelambir 5 Gg. Hasan... & $-0.010447 \ldots$ & 6 & Tidak Layak \\
\hline
\end{tabular}

Gambar 7 Pengujian Untuk Kelayakan Pembuatan Instalasi Pipa Air

\section{KESIMPULAN}

Berdasarakan perumusan dan pembahasan bab-bab sebelumnya dapat diambil kesimpulan sebagai berikut :

1. Dalam menerapkan Metode MOORA untuk sistem pendukung keputusan kelayakan pembuatan jaringan baru instalasi pipa air untuk distribusi masyarakat pada PDAM Tirtanadi yaitu dengan memasukkan algoritma perhitungan ke dalam source code program, selanjutnya algoritma yang telah di masukkan ke dalam source code program akan menghitung secara otomatis proses kelayakan pembuatan jaringan baru instalasi pipa air untuk distribusi masyarakat.

2. Dalam merancang aplikasi berbasis Dekstop Programming yang dapat digunakan untuk kelayakan pembuatan jaringan baru instalasi pipa air untuk distribusi masyarakat pada PDAM Tirtanadi, yaitu pertama kita tentukan dahulu kriterianya, kemudian mengetahui data lokasi atau daerah yang ingin melakukan pembuatan jaringan baru instalasi pipa air yang akan dijadikan sebagai objek dalam pembuatan jaringan baru instalasi pipa air untuk ditribusi masyarakat, selanjutnya melakukan proses penilaian dan terakhir melakukan perhitungan terhadap data lokasi hasil survei yang ada.

3. Sistem yang telah dirancang selanjutnya diuji dan diimplementasikan dengan memasukkan data-data sesuai dengan yang ada pada bab-bab sebelumnya, kemudaian jika hasil outputnya sesuai dengan data manual maka dalam pengujian ini sistem berjalan dengan baik, menambahkan data ke database, perintah update untuk merubah data di database, perintah delete untuk menghapus data di database.

\section{DAFTAR PUSTAKA}

[1] Algoritma Dan Pemrograman, 2019, Defenisi dan Simbol Flowchart. Ditemukenali Dari: https://www.google.com/Fendah ks.staff.gunadarma.ac.id [12 Januari 2019].

[2] Elizabeth dan Darmawan H, 2015, Sistem Informasi Pemakaian Sparepart Mesin Packing pada $P T$. XYZ, Palembang: STMIK GI MDP

[3] Harahap Dkk, 2013, Faktor-Faktor Yang Mempengaruhi Permintaan Air Minum Pada Perusahaan Daerah Air

Minum (PDAM) Tirtanadi Medan, Medan: Universitas Sumatera Utara

[4] Manurung, 2018, Sistem Pendukung Keputusan Pemilihan Guru Dan Pegawai Terbaik Menggunakan Metode Moora, Universitas Metodist Indonesia

[5] Munawar, 2018, Analisis Perancangan Sistem Berorientasi Objek Dengan UML, Bandung :Infromatika.AGRIFOR. 15.

[6] Muqtadir dan Purdianto, 2013, Sistem Pendukung Keputusan Kenaikan Jabatan Menggunakan Metode Profile Matching, Tuban: Universitas PGRI Ronggolawe 
[7] Nofriansyah dan Defit, 2017, Multi Criteria Decision Making Pada Sistem Pendukung Keputusan, Yogyakarta : Budi Utama

[8] Oktarina dan Kuswantoro, 2011, Pembelajaran Berbasis It Aplikasi Program Ms.Acces Untuk

Meningkatkan Pemahaman Mahasiswa Pada Pokok Bahasan Inventarisasi, Semarang: Universitas Negeri Semarang

[9] Ramdhani M, 2019, Mengenal Microsoft Visual Basic 2008. Ditemukenali Dari: https://asepramdhani.files.wordpress.com [18 Januari 2019].

[10] Rokhman Dkk, 2017, Pengembangan Sistem Penunjang Keputusan Penentuan UKT Mahasiswa Dengan Menggunakan Metode Moora Studi Kasus Politeknik Negeri Malang, Malang: Politeknik Negeri Malang

[12] Rosa, 2014, Rakayasa Perangkat Lunak, Bandung :Infromatika 